\title{
First report of gray mold rot disease on tomato (Solanum lycopersicum L.) caused by Botrytis cinerea in Malaysia
}

\author{
Ahmadu Tijjani ${ }^{1} \cdot$ Siti Izera Ismail ${ }^{1}$ - Ahmad Khairulmazmi ${ }^{1} \cdot$ Omar Dzolkhifli ${ }^{1}$ \\ Received: 4 February 2018 / Accepted: 9 August 2018 / Published online: 20 August 2018 \\ (C) Società Italiana di Patologia Vegetale (S.I.Pa.V.) 2018
}

In April 2015, tomato (Solanum lycopersicum L.) fruits with gray mold symptoms (approximately $65 \%$ incidence) were observed at storage in Cameron Highlands (Pahang, Malaysia). The symptoms observed were white circular halo spots with extensive growth of mycelium that developed into water-soaked lesions covered with abundant gray spores. Isolation by transferring little tissue samples (approximately $5 \mathrm{~mm} \times 5 \mathrm{~mm}$ ) of symptomatic fruits onto Petri plates containing PDA (potato dextrose agar) yielded colonies with fast growing aerial gray mycelia. Conidia $(n=40)$ measured 9.7$17.1 \times 6.6-10.5 \mu \mathrm{m}$, and were smooth, one-celled, ellipsoidal, globose and borne on tree-like conidiophores. Sclerotia $(1.9-4.5 \times 1.7-4.0 \mathrm{~mm})$ were black, spherical or irregular in shape and formed in concentric or edge of the culture plates. These morphological characteristics are similar to the description of Botrytis cinerea Pers. (Javed et al. 2017). The primer pair ITS4/ITS5 of rDNA and part of glyceraldehyde-3-phosphate dehydrogenase gene (G3PDH) were used for amplification and sequencing of a representative isolate (BCH02). The sequences obtained (GenBank Accession Nos. KU992694 and KY201457) showed 100\% similarity with B. cinerea (AJ716294 and AJ705006). Phylogenetically, the isolate (BCH02) clustered in one clade with the related species of $B$. cinerea available in the GenBank (AJ705002 - AJ705006) based on G3PDH gene region (Staats et al. 2005). Tomato fruits wounded by piercing with a sterilized hypodermic needle were inoculated each with $60 \mu \mathrm{l}$ of a conidial suspension $\left(10^{6}\right.$ conidia $\left./ \mathrm{ml}\right)$, and subsequently incubated in a moist chamber at 90 to $100 \%$ relative humidity (RH) for 7 days at $25{ }^{\circ} \mathrm{C}$, with a 12 -h photoperiod. Control fruits were inoculated with sterile distilled water. Inoculated fruits exhibited symptoms similar to those observed in the field, while the controls remain symptomless. Botrytis cinerea was re-isolated from the rotten tissues of the inoculated tomatoes and the morphological characteristics were similar to the original isolates. The reference isolate (BCH02) was deposited in the Microbial Collection Unit (UNiCC) of the Institute of Biosciences (IBS), University Putra Malaysia (UPM) with depository accession number (UPMC 1310). To the best of our knowledge, this is the first report of $B$. cinerea causing post-harvest fruits rots on tomato in Malaysia.

\section{References}

Javed S, Javaid A, Anwar W, Majeed RA, Akhtar R, Naqvi SF (2017) First report of Botrytis bunch rot of grapes caused by Botrytis cinerea in Pakistan. Plant Dis 101:1036

Staats M, van Baarlen P, van Kan JA (2005) Molecular phylogeny of the plant pathogenic genus Botrytis and the evolution of host specificity. Mol Biol Evol 22:333-346
Ahmadu Tijjani

tijjaniahmadu72@gmail.com

1 Department of Plant Protection, Faculty of Agriculture, Universiti Putra Malaysia, UPM, 43400 Serdang, Selangor Darul Ehsan, Malaysia 